University of Nebraska - Lincoln

DigitalCommons@University of Nebraska - Lincoln

2000

\title{
Evidence for Edge Effects on Multiple Levels in Tallgrass Prairie
}

\author{
Maiken Winter \\ University of Missouri \\ Douglas $\mathrm{H}$. Johnson \\ USGS Northern Prairie Wildlife Research Center, Douglas_H_Johnson@usgs.gov \\ John Faaborg \\ University of Missouri, FaaborgJ@missouri.edu
}

Follow this and additional works at: https://digitalcommons.unl.edu/usgsnpwrc

Part of the Other International and Area Studies Commons

Winter, Maiken; Johnson, Douglas H.; and Faaborg, John, "Evidence for Edge Effects on Multiple Levels in Tallgrass Prairie" (2000). USGS Northern Prairie Wildlife Research Center. 197.

https://digitalcommons.unl.edu/usgsnpwrc/197

This Article is brought to you for free and open access by the US Geological Survey at DigitalCommons@University of Nebraska - Lincoln. It has been accepted for inclusion in USGS Northern Prairie Wildlife Research Center by an authorized administrator of DigitalCommons@University of Nebraska - Lincoln. 


\title{
EVIDENCE FOR EDGE EFFECTS ON MULTIPLE LEVELS IN TALLGRASS PRAIRIE ${ }^{1}$
}

\author{
MAIKEN WINTER ${ }^{2}$ \\ Division of Biological Sciences, University of Missouri, Columbia, MO 65211 \\ DOUGLAS H. JoHNSON \\ U.S. Geological Survey, Northern Prairie Wildlife Research Center, Jamestown, ND 58401 \\ JOHN FAABORG \\ Division of Biological Sciences, University of Missouri, Columbia, MO 65211
}

\begin{abstract}
We tested how edges affect nest survival and predator distribution in a native tallgrass prairie system in southwestern Missouri using artificial nests, natural nests of Dickcissels (Spiza americana) and Henslow's Sparrows (Ammodramus henslowii), and mammal track stations. Survival of artificial nests was lower within $30 \mathrm{~m}$ of forest edge. Nesting success of Dickcissels and Henslow's Sparrows was lower within $50 \mathrm{~m}$ to a shrubby edge than at greater distances, whereas fates of nests were not related to distances to roads, agricultural fields, or forests. Evidence from clay eggs placed in artificial nests indicated that mid-sized carnivores were the major predators within $30 \mathrm{~m}$ of forest edges. Furthermore, mid-sized carnivores visited track stations most frequently within $50 \mathrm{~m}$ of forest edges. Because proximity of woody habitat explained more variation in nest survival and mammal activity than did fragment size, it appears that edge effects were more pronounced than area effects. Edge effects appeared to be caused mainly by greater exposure of nests to midsized carnivores. We argue that, based on edge avoidance behavior, "grassland-interior" species such as the Henslow's Sparrow respond to edge effects mainly by a decrease in density, whereas habitat generalists such as the Dickcissel are affected mainly by a decrease in nesting success.
\end{abstract}

Key words: Dickcissel, edge effect, habitat fragmentation, Henslow's Sparrow, mammal distribution, nest success, tallgrass prairie.

\section{INTRODUCTION}

Grassland-nesting birds, like forest nesters, can have lower nesting success in smaller than in larger habitat fragments (Johnson and Temple 1990, Winter and Faaborg 1999). This relationship between nesting success and fragment size ("area effect") might be caused by elevated frequencies of nest predation close to edge, because small fragments have a higher proportion of their area close to an edge of a habitat (sensu Temple 1986). In addition, edge habitat presumably supports a greater abundance and species diversity of nest predators (Gates and Gysel 1978, Johnson and Temple 1990). Edges also can support a larger number of the brood-parasitic Brown-headed Cowbird (Molothrus ater) (Johnson and Temple 1990). In this paper, we refer to an edge as a "junction between two dis-

\footnotetext{
${ }^{1}$ Received 27 May 1999. Accepted 14 January 2000.

${ }^{2}$ Current address: College of Environmental Science and Forestry, State University of New York, Syracuse, NY, e-mail: mwinter02@syr.edu
}

similar habitat types" (Faaborg et al. 1993), and to "edge effects" as differential frequencies of nest predation or brood parasitism close to edges (Gates and Gysel 1978).

Edge effects have been intensively studied in forest fragments with both artificial nests (Paton 1994) and natural nests (Donovan et al. 1995, Robinson et al. 1995). Generally, these studies indicate that depredation is exacerbated close to an edge, and in small fragments (Robinson et al. 1995). The little research that has been done on edge and area effects on nesting success in grassland-nesting birds indicates a similar pattern (Johnson and Temple 1990, Winter and Faaborg 1999). Although increased predation pressure in fragmented habitats is thus potentially an important factor contributing to population declines in many grassland-nesting birds (Knopf 1994), very little is known about the interaction between predator distributions and habitat fragmentation and the subsequent effect on nesting success of grassland-nesting birds (Greenwood et al. 1995).

We investigated edge and area effects in a 
TABLE 1. Prairie fragments in southwestern Missouri and the types of study done in each indicated by an "X".

\begin{tabular}{|c|c|c|c|c|}
\hline Prairie fragment & Size (ha) & $\begin{array}{l}\text { Artificial nests } \\
\quad(1995)\end{array}$ & $\begin{array}{l}\text { Natural nests } \\
(1995-1997)\end{array}$ & $\begin{array}{c}\text { Mammals } \\
(1996-1997)\end{array}$ \\
\hline Pawhuska & 31.0 & $X$ & $X$ & $X$ \\
\hline Little Osage & 32.0 & $X$ & & \\
\hline Mon-Shon & 32.4 & $X$ & $X$ & $X$ \\
\hline Catlin & 43.7 & & $X$ & $X$ \\
\hline Gay Feather & 47.0 & $X$ & & $X$ \\
\hline Treaty Line & 64.0 & & $X$ & \\
\hline Clear Creek & 77.7 & $\mathrm{X}$ & & $X$ \\
\hline Cook Memorial Meadow & 113.0 & $\mathrm{X}$ & & \\
\hline Mo-No-I & 122.0 & $X$ & $\mathrm{X}$ & $X$ \\
\hline Niawathe & 130.0 & $X$ & $X$ & $X$ \\
\hline Stony Point & 259.0 & & $\mathrm{X}$ & \\
\hline Osage & 506.0 & $\mathrm{X}$ & $X$ & $X$ \\
\hline Prairie State Park & $1,084.0$ & & $X$ & \\
\hline
\end{tabular}

tallgrass-prairie system in southwestern Missouri using three approaches: (1) an artificial-nest study, (2) an examination of nesting success and cowbird parasitism in Dickcissels (Spiza americana) and Henslow's Sparrows (Ammodramus henslowii), and (3) a study of activity patterns of mammals. Our hypotheses were: (1) predation frequencies of both artificial and natural nests would be higher close to an edge, and (2) if edge effects exist, then they can be at least partially explained by increased activity of mammalian nest predators close to edge habitat. We also hypothesized that edge effects can cause the following area effects: (3) predation frequencies of both artificial and natural nests would be higher in small versus large prairie fragments, and (4) nest predators would be more frequent in small than in large prairie fragments.

\section{METHODS}

\section{STUDY AREA AND STUDY PLOTS}

We conducted this study during 1995-1997 in Vernon, Barton, and Dade Counties in southwestern Missouri in nine native tallgrass prairie fragments, which ranged in size from 31 to 1,084 ha (Table 1). The prairie size used for calculations was smaller than the total size of the preserve if prairie areas were separated by wide $(>50 \mathrm{~m})$ wooded drainages. Prairie fragments were similar in topography (generally flat or slightly hilly) and plant composition. Dominant plant species were big bluestem (Andropogon gerardii), little bluestem (Schizochyrium scoparium), Indiangrass (Sorghastum nutans), sunflowers (Helianthus spp.), milkweeds (Asclepias spp.), blazing star (Liatris spicata), and sensitive briar (Schrankia nuttallii). All prairies were managed with prescribed burning and haying throughout the study.

We differentiated four edge types: (1) forest edge: an abrupt change from grassland to habitat with woody stems $>2.5 \mathrm{~cm}$ dbh (diameter at breast height) in a strip at least $15 \mathrm{~m}$ wide that dissects $\geq 75 \%$ of a fragment or borders at least one side of a fragment, (2) shrubby edge: an abrupt change from grassland to habitat with woody stems $<2.5 \mathrm{~cm}$ dbh in at least a $200-\mathrm{m}$ long strip along borders of prairies or in patches of at least $20 \times 100 \mathrm{~m}$ within prairies, (3) agricultural edge: cropland fields (only soybean and corn in our study) that bordered a prairie fragment, and (4) road edge: roads the size of two-lane paved country roads (about $7 \mathrm{~m}$ wide) or larger. Unpaved roads were not considered as road edge, but were typically shrubby edge. A change from prairie to hay-meadow or fields enrolled in the Conservation Reserve Program (CRP) was not considered an edge because we assumed that these habitats were similarly used by grassland birds and that nest predators would not perceive such change in habitat as travel lanes.

\section{ARTIFICIAL NEST EXPERIMENT}

In 1995, we determined frequencies of nest predation at various distances from a forest edge by placing one artificial nest within each of three distance intervals: $0-15 \mathrm{~m}, 30-45 \mathrm{~m}$, and $60-$ $75 \mathrm{~m}$. We chose these distance intervals because previous work had indicated that edge effects 
occur mainly within $50 \mathrm{~m}$ of an edge (Burger et al. 1994). In each of nine prairies we placed artificial nests along 3-10 parallel transects, depending on the length of the forest edge. Transects were $50 \mathrm{~m}$ apart and perpendicular to the edge. To reduce the probability that predators followed transect lines (Laurence and Yensen 1991), we placed nests at a random number of paces from each transect, alternating between left and right sides. Furthermore, we wore rubber boots and latex gloves during the experiment to reduce human scent (Small and Hunter 1988), because human scent has been shown to increase predation of artificial nests (Whelan et al. 1994). However, the efficacy of such precautions is unknown (Major and Kendal 1996). All artificial nests were handled in the same manner; any possible bias in predation frequencies is therefore assumed not to affect our comparisons (Donovan et al. 1997). However, this assumption is true only if the potential types of nest predator were the same at different distances from edge habitat. Artificial nests consisted of commercial canary wicker baskets placed on the ground and surrounded with litter (Burger et al. 1994). In each nest we placed one Northern Bobwhite (Colinus virginianus) egg and one clay egg that resembled quail eggs in form, color, and size. The clay egg enabled us to determine the species of nest predator, based on claw, tooth, or bill marks (Porneluzi 1996). If the quail or clay egg was missing or damaged after a 12-day exposure, the nest was classified as depredated. An exposure length of 12 days was used to mimic the natural length of the incubation period of most grassland songbirds.

Immediately following the experiment, we characterized the vegetation at each artificial nest site by placing a $50 \times 30$-cm Daubenmire (1959) frame over each nest. We then determined (1) percent ground cover (to total 100\%) by litter, grasses, forbs, woody vegetation, and soil within the Daubenmire frame, (2) the number of woody stems within each frame, (3) litter depth and vegetation height at each of the four corners of the frame, (4) visual obstruction in the middle of each frame, with four readings in each cardinal direction at 4-m distance and 1-m height (Robel et al. 1970), and (5) percentage of the nest that was covered by vegetation.

\section{NATURAL NESTS}

We searched for nests of Dickcissels and Henslow's Sparrows during each field season (early
May to end of July, 1995-1997) by walking haphazard paths throughout the prairie fragments, restricting nest search efforts to grassland habitats, and observing flushed birds when they returned to their nest (Winter 1999). Each nest was checked every 3-4 days to determine nest fate and presence or absence of cowbird eggs or nestlings. Nests that fledged at least one young of the parental species were considered successful. A nest was considered successful if we observed evidence of fledging such as feather sheaths or feces in the nest, a flattened nest rim, chipping or feeding adults, or presence of one or more fledglings in the immediate area. Because almost all nest failures were due to predation, frequency of nest mortality and nest predation are virtually synonymous in this study.

Nest characteristics were measured within one week after activity at a nest had ceased. At each nest we visually estimated the distance to the nearest edge habitat in $10-\mathrm{m}$ intervals. Habitat edges farther than $100 \mathrm{~m}$ were combined into one category. We measured the height above ground of each nest and estimated the percentage of the nest that was covered by vegetation. We characterized nest vegetation in the same manner as at artificial nests, except that we measured vegetation not only directly at the nest, but also at four locations $0.5 \mathrm{~m}$ from the nest in each cardinal direction. For each nest we calculated the mean for each of the five measuring points, and used the mean of those five values for analyses.

\section{TRACK STATIONS}

In 1996 and 1997, we used a total of 825 track stations to assess mammalian activity at various distances from a forested edge. We placed track stations in eight prairie fragments along five parallel transects at three distance intervals $(0-10$ $\mathrm{m}, 40-60 \mathrm{~m}$, and $90-110 \mathrm{~m}$ ) from a forest edge. Transects were $50 \mathrm{~m}$ apart and perpendicular to the edge. Each interval had one track station that consisted of a pair of $0.5 \times 1.0-\mathrm{m}$ sheets of 0.32 gauge aluminum. Aluminum sheets were covered with soot with an acetylene torch (Heske 1995, Dijak 1996), and were set in pairs next to each other on level ground. To attract mammals to the plates, we put a cotton swab soaked in cod-liver oil on the ground between the two plates. The tracks left by mammals visiting the plates allowed identification of the species or at least the size of mammal. Mammals no larger 
than a tree squirrel (Sciurus spp.) were considered "small" (tracks were not identifiable to the species level); larger mammals were considered "mid-sized" (tracks generally were identifiable to the species level). Track stations were deployed three or four times throughout June and July, each time being placed for $24 \mathrm{hr}$ at a different random number of steps along and to the right or left of the transect within each distance interval. Because we could not distinguish between different individuals of the same species, we could not determine whether more than one individual of the same species visited the same track station, or if the same individual visited several track stations (Heske 1995). Therefore, we defined the visitation frequency of plates as the number of plates that were visited by one or more individuals out of all plates used in the experiment. This frequency was used as an index of mammalian activity.

\section{STATISTICAL ANALYSIS}

We used stepwise logistic regression (proc logistic; SAS/STAT 1995) to determine which explanatory variables (distance to edge, log-transformed fragment size, and nest vegetation variables) were most important in influencing survival of artificial and natural nests, cowbird parasitism, and distribution of nest predators. For natural nests, we investigated the effect of distance to a shrubby edge only, because sample sizes were too small for other edge types. In our logistic regressions, we treated each nest as a separate observation. Because vegetation variables were highly correlated, we used principal components analysis (James 1971) to avoid problems associated with multicollinearity. Percent nest cover was not included in the principal component analysis because this variable can be independent of vegetation variables depending on nest placement. Detailed tables of principal component scores are listed in Winter (1998). In all analyses, distance to edge was treated as a continuous variable.

The use of logistic regression for natural nests is problematic because this analysis treats every nest the same, without taking differences in exposure time into account. A more conservative approach was used to investigate whether distance to edge affected nesting success, by calculating mean rates and standard errors of daily nest survival (Mayfield 1975, Johnson 1979) separately for three distance intervals $(<50 \mathrm{~m}$,
50-100 m, and >100 m). We were not able to divide distances into finer intervals because we found few nests close to an edge. Because predation frequencies can differ between type of edge (Suarez et al. 1997), we distinguished among the four edge types (see above). Only for Dickcissels was the frequency of cowbird brood parasitism high enough for stepwise logistic analysis, again distinguishing among three distance intervals $(<50 \mathrm{~m}, 50-100 \mathrm{~m}$, and $>100$ $\mathrm{m})$.

To investigate how distance to edge and fragment size affected activity patterns of mammals, we calculated the mean visitation rates for each distance interval in each prairie for all mammals combined as well as separately for small and mid-sized carnivores. Because visitation rates within a prairie were not independent, we used ANCOVA (with repeated measures within prairie) with an unstructured covariance matrix (proc mixed; SAS/STAT 1997) with both distance to edge and log-transformed fragment size as explanatory variables. Visitation frequency of track plates by mammals did not differ between 1996 and 1997 (1996: $\bar{x}=0.08 \pm 0.02 ; 1997$ : $\bar{x}=0.09 \pm 0.02 ; P>0.8, n=48)$, and year did not interact with explanatory variables $(P>$ 0.40 ); therefore we pooled data from both years for all analyses.

We used linear regression (proc reg; SAS Institute 1995) to determine whether fragment size affected nesting success rates of artificial and natural nests, frequency of brood parasitism, frequency of predation on artificial nests, and activity frequency of mammals. In these analyses, we avoided pseudoreplication by using the prairie fragment as our sampling unit with mean frequencies (of artificial nest predation, nesting success, cowbird parasitism, mammal activity) in each prairie fragment as the dependent variable and the logarithm of fragment size as the explanatory variable. Because sample sizes varied among prairies, we used the inverse of the standard error of mean frequencies per fragment as a weighting factor in the analyses. Data were analyzed with SAS (1995, 1997), and the significance level was set at 0.05 . Data are given as means $\pm \mathrm{SE}$.

\section{RESULTS}

In our study, edge effects were more pronounced than area effects. Nest predation in both Dickcissels and Henslow's Sparrows, brood parasit- 
TABLE 2. Tests of effects of distance to edge, fragment size, and vegetation structure on nesting success and its correlates. Presented are results from stepwise logistic regression or repeated-measures ANCOVA (animal track data only). In the logistic regressions, the dependent variables were log (ln) fragment size and three principal components describing vegetation structure at the nest. In repeated-measures ANCOVA, distance to edge (categorical) and ln fragment size were the explanatory variables.

\begin{tabular}{|c|c|c|c|c|c|}
\hline & $n$ & Variables entered & Slope $\pm \mathrm{SE}^{\mathrm{a}}$ & $x^{2}$ & $P$ \\
\hline \multicolumn{6}{|l|}{ Logistic regression } \\
\hline $\begin{array}{l}\text { Artificial nest survival } \\
\text { Nest success }\end{array}$ & 193 & PC1 & $-0.50 \pm 0.12$ & 18.5 & $<0.001$ \\
\hline \multirow[t]{2}{*}{ Dickcissel $^{\mathrm{b}}$} & 111 & In fragment size & $-0.44 \pm 0.004$ & 8.5 & $<0.01$ \\
\hline & & $\mathrm{PC} 1$ & $-0.34 \pm 0.13$ & 6.5 & 0.01 \\
\hline Henslow's Sparrow ${ }^{b}$ & 49 & Distance to edge & $-0.25 \pm 0.11$ & 5.6 & $<0.03$ \\
\hline Brood parasitism ${ }^{\mathrm{b}}$ & 111 & Distance to edge & $1.14 \pm 0.14$ & 4.8 & 0.01 \\
\hline \multicolumn{6}{|l|}{ Depredation of artificial nests by } \\
\hline \multirow[t]{2}{*}{ all mammals } & 169 & PC1 & $0.38 \pm 0.12$ & 9.6 & $<0.01$ \\
\hline & & $\mathrm{PC} 3$ & $-0.31 \pm 0.15$ & 4.5 & $<0.05$ \\
\hline mid-sized carnivores & 169 & Distance to edge & $0.74 \pm 0.37$ & 4.1 & $<0.05$ \\
\hline \multirow[t]{2}{*}{ small mammals } & 169 & $\mathrm{PC} 1$ & $0.40 \pm 0.13$ & 9.2 & $<0.01$ \\
\hline & & PC3 & $-0.41 \pm 0.16$ & 6.5 & 0.01 \\
\hline \multirow{3}{*}{$\begin{array}{l}\text { Repeated-measures ANCOVA } \\
\text { all mammals }\end{array}$} & $n$ & Variables in model & Slope $\pm S E$ & $F$ & $P$ \\
\hline & 48 & Distance to edge & & 11.0 & $<0.001$ \\
\hline & & ln fragment size & $-0.03 \pm 0.01$ & 5.8 & 0.05 \\
\hline \multirow{2}{*}{ mid-sized carnivores } & 48 & Distance to edge & & 7.7 & 0.001 \\
\hline & & ln fragment size & $0.001 \pm 0.007$ & 0.0 & 0.83 \\
\hline \multirow[t]{2}{*}{ small mammals } & 48 & ln fragment size & $-0.01 \pm 0.001$ & 6.5 & $<0.01$ \\
\hline & & Distance to edge ${ }^{c}$ & & 5.3 & 0.06 \\
\hline
\end{tabular}

${ }^{a}$ Logistic regression calculated the probability that a nest fails or that a nest is parasitized. Thus a negative parameter indicates that the probability that a nest fails or gets parasitized decreases with increasing fragment size or vegetation variable.

The analysis includes nests in proximity to shrubby edge only.

c Slopes are presented graphically in Figure 2.

ism by Brown-headed Cowbirds of Dickcissels, predation of artificial nests by mid-sized carnivores, and activity of both small and mid-sized mammalian nest predators were higher within 50 $m$ of edge habitat (Table 2). Fragment size influenced nest success of Dickcissels and tended to affect the activity of small-mammalian nest predators; nest survival increased and smallmammal activity tended to decrease with fragment size. Survival of artificial nests was mostly related to vegetation parameters.

Survival of artificial nests increased with distance to forested edge (Fig. 1a). Because the relationship appeared nonlinear, we also looked for a quadratic effect; however, the quadratic model (Wald $\chi^{2}=2.0, P>0.05, n=200$ ) did not improve the fit significantly from a univariate model (Wald $\chi^{2}=3.9, P=0.05$ ). The apparent edge effect was confounded with vegetation; stepwise logistic regression selected only one variable, the first principal component (PC1) (Table 2). This component summarized a range of high to low scores on litter depth and litter cover, as well as low to high scores on cover by forbs and bare soil. Successful nests were thus characterized by greater depth and coverage by litter and lower coverage by forbs and bare soil $\left(t_{197}=-4.8, P<0.001\right)$. To reduce this confounding effect, we removed variation in PC1 due to distance to edge by regressing $\mathrm{PC} 1$ on distance to edge. The resulting residuals were then entered in another stepwise logistic regression. This stepwise regression selected fragment size (Wald $\chi^{2}=6.2, P=0.01, n=200$ ) and percent nest cover (Wald $\chi^{2}=4.9, P<0.05$ ); with increasing fragment size or increasing nest cover, the probability of nest predation decreased. Distance to edge thus seemed to be of less importance to the survival of artificial nests than fragment size and vegetation characteristics at the nest. The initial significant relation of nest survival to distance to edge might therefore be caused by a correlation with other variables.

Mid-sized carnivores were the only nest predators that depredated artificial nests more frequently within $30 \mathrm{~m}$ of edge than at greater distances (Fig. 1b), with American badgers (Taxidea taxus) being the only mid-sized carnivore that depredated nests at a distance $>60 \mathrm{~m}$ from edge habitat. Distance to edge was the only var- 

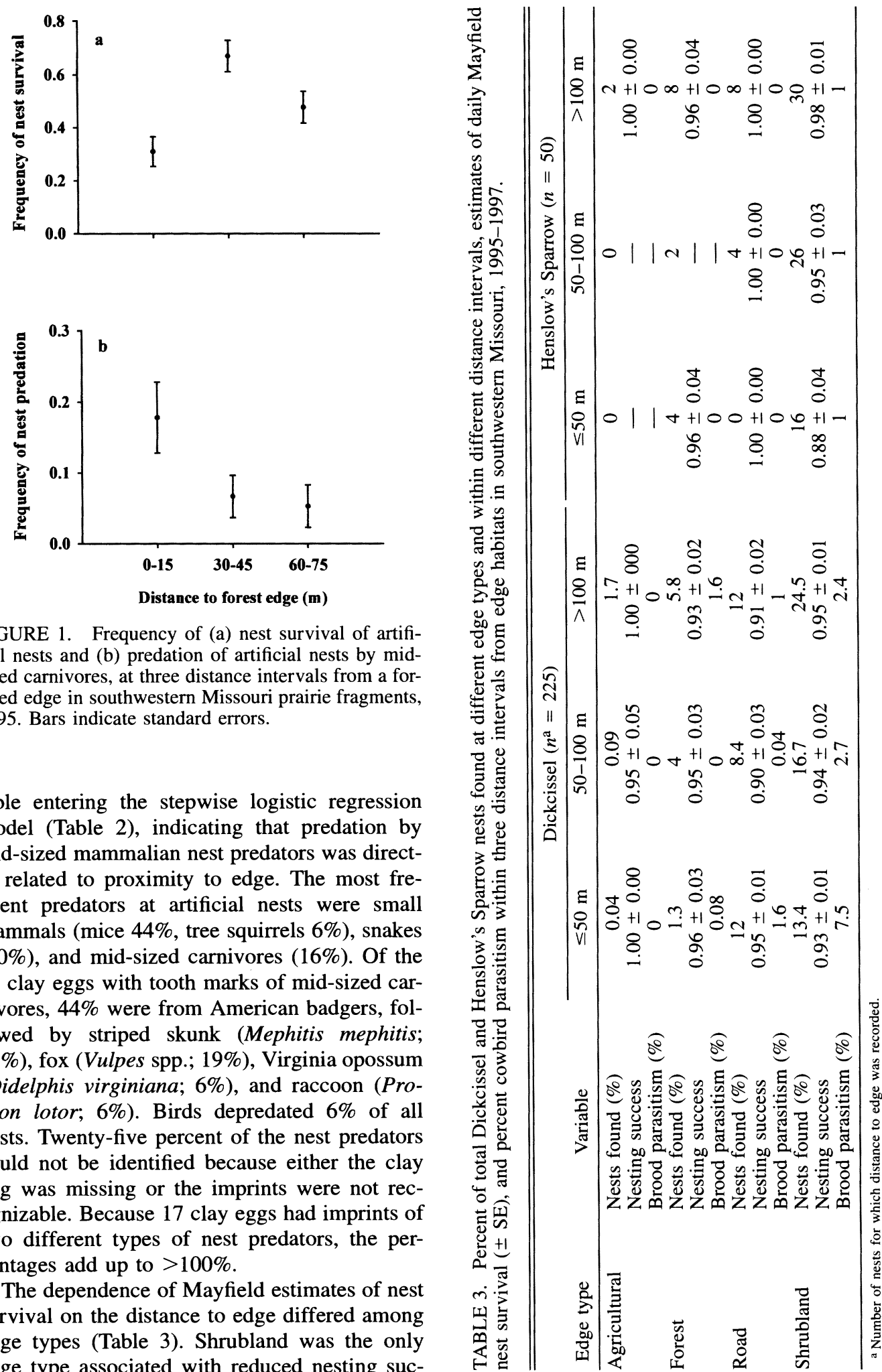

FIGURE 1. Frequency of (a) nest survival of artificial nests and (b) predation of artificial nests by midsized carnivores, at three distance intervals from a forested edge in southwestern Missouri prairie fragments, 1995. Bars indicate standard errors.

iable entering the stepwise logistic regression model (Table 2), indicating that predation by mid-sized mammalian nest predators was directly related to proximity to edge. The most frequent predators at artificial nests were small mammals (mice $44 \%$, tree squirrels $6 \%$ ), snakes $(20 \%)$, and mid-sized carnivores (16\%). Of the 16 clay eggs with tooth marks of mid-sized carnivores, $44 \%$ were from American badgers, followed by striped skunk (Mephitis mephitis; 25\%), fox (Vulpes spp.; 19\%), Virginia opossum (Didelphis virginiana; 6\%), and raccoon (Procyon lotor; $6 \%$ ). Birds depredated $6 \%$ of all nests. Twenty-five percent of the nest predators could not be identified because either the clay egg was missing or the imprints were not recognizable. Because 17 clay eggs had imprints of two different types of nest predators, the percentages add up to $>100 \%$.

The dependence of Mayfield estimates of nest survival on the distance to edge differed among edge types (Table 3). Shrubland was the only edge type associated with reduced nesting suc- 
cess close to an edge; this negative relationship was slightly more pronounced in Henslow's Sparrows than in Dickcissels. Proximity to road edges seemed to have a positive effect on Dickcissel nesting success (Table 3), but this relationship was not significant (Wald $\chi^{2}=0.2, P$ $>0.05, n=87$ ). Too few nests were found within $50 \mathrm{~m}$ of a forest to investigate effects of that type of edge.

Stepwise logistic regression revealed that fragment size was more important than distance to a shrubby edge in predicting Dickcissel nesting success (Table 2). However, distance to shrubby edge and fragment size were correlated ( $r=0.31, P<0.001$ ), and this correlation could mask any existing edge effect. Therefore, we removed the variation in distance to edge due to fragment size by calculating residuals from a regression of distance to edge on fragment size, and entered those residuals in another stepwise logistic regression. Again, distance to edge was not selected, indicating that the apparent edge effect near shrubby edges might not be directly caused by the distance to edge. The only other variable that entered the stepwise logistic regression was the first principal component (Table 2). This component describes a continuum from low to high litter depth, vegetation height, and visual obstruction, indicating that Dickcissel nesting success increased with increasing vegetation height and density. In contrast to Dickcissels, the only factor that influenced Henslow's Sparrow nesting success was distance to edge; its nest success was lower within $50 \mathrm{~m}$ than at farther distances (Table 2 and 3).

Frequency of brood parasitism by Brownheaded Cowbirds on Dickcissels was highest within $50 \mathrm{~m}$ of shrubby habitats (Table 3 ), and increased significantly with proximity to shrubby edge (Table 2). In Henslow's Sparrows, cowbird parasitism was negligible; only 3 of 59 nests $(5 \%)$ were parasitized. In this species, the nearest edge to all parasitized nests was shrubby (Table 3).

Activity patterns of both small and mid-sized carnivores were significantly higher within $50 \mathrm{~m}$ of a forested edge than at greater distances (Fig. 2, Table 2). Fragment size tended to influence activity patterns of only small mammals (Table 2). Visitation frequency of track stations by mammals was low; only $0.8 \%$ of all plates were visited. The most frequently encountered group was small mammals (63\% of all visits). Species

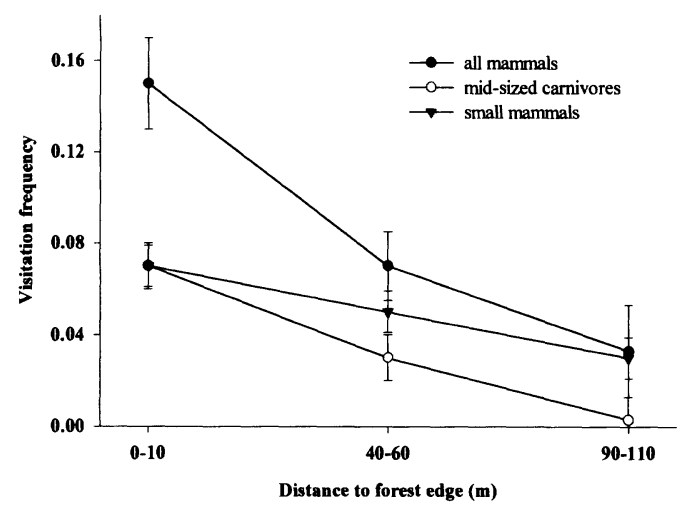

FIGURE 2. Visitation frequencies of mammals at three distance intervals from a forested edge in fragments of native tallgrass prairie in southwestern Missouri, 1996-1997. Data are shown separately for all mammals combined, mid-sized carnivores, and small mammals. Least squares means and their standard errors are shown to control for confounding variation due to fragment size.

composition of mid-sized carnivores at track stations differed from that determined from clay eggs. Out of 25 visits by mid-sized carnivores, $40 \%$ were by Virginia opossums, $36 \%$ by raccoons, $20 \%$ by striped skunks, and $4 \%$ by coyotes (Canis latrans). Badgers and foxes did not visit track stations; these two species thus depredated artificial nests more frequently than their presence at track stations would suggest.

Fragment size did not influence the fates of artificial nests, although the frequency of artificial nest predation by mid-sized carnivores was higher in small than in large fragments (Table 4). Dickcissel nesting success decreased with decreasing size of a prairie fragment, whereas Henslow's Sparrow nesting success was not affected by fragment size (Table 4; Winter and Faaborg 1999). Brood parasitism in Dickcissels was not significantly related to fragment size. The only other relationship with fragment size was found for activity patterns of small mammals; their visits to track plates tended to be more frequent in small prairie fragments $(0.1>$ $P>0.05$; Table 4).

\section{DISCUSSION}

In southwestern Missouri prairie fragments, edge effects were more pronounced than area effects (Table 2). Predation on natural nests, brood parasitism, and activity of mid-sized mammalian nest predators tended to increase 
TABLE 4. Effects of fragment size on artificial nests, natural nests, and nest predator distribution in southwestern Missouri prairie fragments.

\begin{tabular}{lccccc}
\hline \multicolumn{1}{c}{ Variable } & $\begin{array}{c}\text { Fragments } \\
\text { used }\end{array}$ & Slope $\pm \mathrm{SE}^{\mathrm{a}}$ & $R^{2}$ & $F$ & $P$ \\
\hline Artificial nest survival & 9 & $0.20 \pm 0.24$ & 0.09 & 0.7 & 0.43 \\
Nesting success: & & & & \\
$\quad$ Dickcissel & $16^{\mathrm{b}}$ & $0.02 \pm 0.01$ & 0.22 & 4.3 & 0.05 \\
$\quad$ Henslow's Sparrow & 9 & $0.01 \pm 0.02$ & 0.07 & 0.6 & 0.45 \\
Cowbird parasitism of Dickcissel nests & 9 & $-0.06 \pm 0.11$ & 0.04 & 0.3 & 0.59 \\
Predators art artificial nests & & & & \\
$\quad$ All mammals & 9 & $-0.45 \pm 0.20$ & 0.38 & 4.9 & 0.06 \\
Mid-sized carnivores & 9 & $-0.12 \pm 0.05$ & 0.46 & 6.0 & $<0.05$ \\
Small mammals & 9 & $-0.15 \pm 0.15$ & 0.13 & 1.0 & 0.35 \\
Birds & 9 & $-0.04 \pm 0.06$ & 0.06 & 0.5 & 0.51 \\
$\quad$ Snakes & 9 & $0.05 \pm 0.09$ & 0.03 & 0.3 & 0.60 \\
Visitors at track plates & & & & \\
$\quad$ All mammals & 8 & $-0.03 \pm 0.01$ & 0.56 & 7.6 & 0.03 \\
Mid-sized carnivores & 8 & $-0.001 \pm 0.007$ & 0.01 & 0.03 & 0.87 \\
Small mammals & 8 & $-0.03 \pm 0.02$ & 0.44 & 3.9 & 0.10 \\
\hline
\end{tabular}

${ }^{a}$ Positive slopes indicate an increase of nesting success, cowbird parasitism, or predator occurrence with fragment size.

$\mathrm{b} n$ is larger than the number of prairie fragments used in the study, because data from several years were combined.

with increasing proximity to woody edge habitat (i.e., shrubby and forested edges). In small fragments, predation frequency of Dickcissel nests and predation frequency of artificial nests by mid-sized carnivores were higher than in large fragments; furthermore, small mammal activity tended to be higher in small fragments (Table 4). Burger et al. (1994) conducted an artificial nest experiment in some of the same prairie fragments and found that the proximity to woody edge was more important than fragment size in determining survival of artificial nests. In contrast to their study, we found that the effect of distance to edge on predation of artificial nests was confounded by vegetation variables.

A decrease in nesting success in close proximity to a woody edge seemed to be associated with greater activity by mid-sized mammalian nest predators close to woody edges. Woody edges in southwestern Missouri prairie fragments thus appear to serve as travel routes for mammalian nest predators, as has been described by other studies on forest/field edges in North America (Gates and Gysel 1978, Dijak 1996). Few other studies have investigated the underlying mechanisms of edge effects (Johnson et al. 1989), because most studies that did document edge effects simply assumed that edge effects occurred due to a higher abundance of nest predators close to edge habitat (Faaborg et al. 1993).

Because areas within $50 \mathrm{~m}$ of woody edges apparently have a higher number of mid-sized mammalian nest predators in southwestern Missouri prairie fragments than areas at greater distances from the edge, woody edges could be "ecological traps" (Gates and Gysel 1978) for grassland-nesting birds. However, many grassland-nesting birds seem to avoid edge habitats (Warner 1994), and might therefore be less susceptible to reduced nest success than shrub- and forest-nesting species (Delisle and Savidge 1996). In southwestern Missouri, nesting success of Henslow's Sparrows and Dickcissels seemed to be similarly negatively affected by proximity to shrubby edges. However, Henslow's Sparrows and Dickcissels differed greatly in habitat selection, and consequently in edge avoidance. This difference could cause these species to be differentially affected by proximity to edge and fragment size. Henslow's Sparrows breed only within grassland habitats with little woody cover (Herkert 1994, Pruitt 1996) and consequently did not nest within woody edges in our study (Winter 1999). On the other hand, Dickcissels are less restricted to grassland habitat (Fretwell 1984, Swanson 1996) and did not avoid edge habitats for breeding. Although we restricted nest searching to uniform grassland habitat, we frequently observed Dickcissels feeding nestlings and fledglings in edge habitat. Consequently, Dickcissel nests were more exposed to increased mammal activity close to edges than were Henslow's Sparrows. Lack of 
edge avoidance in Dickcissels also could contribute to the documented lower nesting success of Dickcissels in small fragments, where the amount of edge habitat is relatively high (Winter and Faaborg 1999).

This paper concentrated on identifying edge effects that act on nesting success. However, other aspects of our research have shown that edge effects also play a role in the distribution and density of prairie birds such as Henslow's Sparrows. Henslow's Sparrows had lower densities in small habitat fragments than in large ones (Winter and Faaborg 1999). This distributional area-sensitivity probably is directly related to the avoidance of edge habitat by this species, which could be an adaptation for predator avoidance. Lima and Valone (1991) showed experimentally that grassland birds that do not fly towards shrubby areas when disturbed ("cover-independent escape tactic") seemed to actively avoid woody edges, and hence decreased greatly in abundance with increasing woody cover. Edge effects can thus be expressed either on a distributional level in terms of density or on a demographic level in terms of nesting success. Based on edge avoidance behavior, we would therefore expect that habitat specialists, such as Henslow's Sparrows, respond to proximity to edge mainly by a decrease in density (distributional edge-sensitivity), whereas habitat generalists like Dickcissels may be mainly affected by a decrease in nesting success (demographic edge-sensitivity).

Cowbird brood parasitism, like nest predation, might be higher for those species that do not avoid edge habitats, because cowbirds seem to prefer habitat edges where they can scan for nests from elevated perch sites (Gates and Gysel 1978). In our study, brood parasitism by Brownheaded Cowbirds had little impact on Dickcissels and Henslow's Sparrows, even though the frequency of cowbird parasitism in Dickcissels increased with proximity to edge. Such an increase of brood parasitism frequency with proximity to edge is typical for both grassland-nesting birds (Johnson and Temple 1990) and forestnesting birds (Brittingham and Temple 1983).

Potential problems were associated with each of the methods we used. Artificial nests did not exhibit a clear edge or area effect. Artificial nests thus did not reflect the full extent of the effect that habitat fragmentation may have on nesting success of grassland-nesting birds, as was exemplified by the results based on natural nests of Dickcissel and Henslow's Sparrow. Numerous studies have criticized the use of artificial nests as substitutes for natural nests (Paton 1994, Major and Kendal 1996). In spite of this criticism, artificial nests still can be useful for detecting some general patterns for which we lack sufficient samples of real nests (Donovan et al. 1997). This is especially true for simulating nests of species that are hard to find, and for which sample size of nests is therefore low, such as ground-nesting grassland passerines. Clay eggs in artificial nests frequently have been used to determine the types of nest predators (Porneluzi 1996). However, species preying on artificial nests might differ from species depredating natural nests because the cues attracting predators are not the same (Major and Kendall 1996). In our study, the species visiting track plates and artificial nests were similar, but their frequencies differed greatly. American badger and striped skunk were the most frequent mid-sized carnivores depredating artificial nests, but opossum and raccoon were the most frequent mid-sized carnivores visiting track plates. Conversely, American badgers and foxes depredated artificial nests more frequently than expected based on their visitation frequencies at track stations. Because the two studies were conducted during different years, this difference might reflect year-to-year variation in mammalian densities, which is frequently observed in mammalian predator communities (Johnson et al. 1989). Track plates presumably reflect general activity patterns of mammals, but track plates did not document the presence of all mammals present in the area. Some species, such as coyotes, were seen frequently, but only once left foot-prints on a track plate. Other species known to be common in southwestern Missouri did not visit track plates at all. Heske (1995) described the same disparity for coyotes, red fox (Vulpes vulpes), and bobcats (Lynx rufus) in southern Illinois; Sargeant et al. (1998) for several carnivores in Minnesota, and G. A. Sargeant (pers. comm.) for swift foxes (Vulpes velox) in Kansas. Although the results of our study are thus not free of uncertainty and possible biases, we are relatively confident that the observed edge effects were real because all approaches revealed similar trends.

Mid-sized mammalian nest predators seemed to be the driving force for the observed patterns. 
However, snakes can also be important nest predators in North American grasslands (Zimmerman 1984), and specifically in Missouri (Thompson et al. 1999); our study was not designed to address the distribution of snakes, and their impact on nest predation. Furthermore, mid-sized carnivores have much larger home ranges than the prairie fragments that we studied. Donovan et al. (1997) suggested that it would be easier to understand the response of predators to edge habitats and thus the relationship between nesting success and proximity to edge habitat if research would focus on the nestsearching behavior of individual predator species in a variety of landscapes (Dijak 1996, Lima and Zollner 1996). The intensity of edge effects and of predation and brood parasitism frequencies can vary with characteristics of the surrounding landscape (Huhta et al. 1996, Donovan et al. 1997). We need to combine both local and large-scale studies to better understand which predators are responsible for edge and area effects in prairie fragments, and to understand how edge effects vary with the type of landscape surrounding prairie fragments.

\section{CONCLUSIONS}

In southwestern Missouri, nesting success of Dickcissels and Henslow's Sparrows decreased with proximity to shrubby edges. Too few nests were found within $50 \mathrm{~m}$ of forested habitats to determine its effect on nesting success. Proximity to roads did not influence nesting success. The main reason for decreased nesting success close to woody edges appeared to be the greater activity of mid-sized mammalian nest predators near woody edges. Removal of woody edges in grassland patches may redistribute movement patterns of mammalian nest predators on a local scale, and could potentially reduce the negative impact of habitat fragmentation on grasslandnesting birds. However, because mid-sized carnivores have large home ranges, it is not enough to manage small, isolated prairie fragments; we need to create large connected open areas lacking woody edges to reduce the total numbers of mammalian nest predators in a given area. The removal of woody vegetation potentially could decrease the number of nest predators in a given area, and may also attract species that avoid habitat edges such as Henslow's Sparrows, Upland Sandpipers (Bartramia longicauda), and Greater Prairie-Chickens (Tympanuchus cupido) (Her- kert et al. 1993). Eventually, such management might help to slow or even halt the sharp decline in many grassland-nesting birds (Peterjohn and Sauer 1993). However, most remaining grasslands in North America (93\% in Missouri) are in private ownership. Landowners should be warned about the negative effects of woody edges, and we need to realize that woody plants do not belong in most parts of the prairie landscape.

\section{ACKNOWLEDGMENTS}

We thank D. Granfors, W. Hochachka, L. Igl, R. Koford, W. Newton, M. Ryan, W. Koenig, and two anonymous reviewers for many comments that greatly improved the manuscript. We also thank our field assistants J. Bernier, M. Harry, P. Kohn, S. Panken, D. Rut$\mathrm{ka}$, and K. Warren. The Missouri Conservation Department, the Missouri Prairie Foundation, The Nature Conservancy, and the Missouri Department of Natural Resources kindly allowed us to conduct our research on their land. This study was funded by the U.S. Geological Survey (Northern Prairie Wildlife Research Center), the Missouri Department of Conservation, the U.S. Fish and Wildlife Service, the Missouri Prairie Foundation, and Sigma Xi.

\section{LITERATURE CITED}

Brittingham, M. C., and S. A. Temple. 1983. Have cowbirds caused forest birds to decline? BioScience 33:31-35.

Burger, L. D., L. W. Burger, And J. FaAborg. 1994. Effects of prairie fragmentation on predation on artificial nests. J. Wildl. Manage. 58:249-254.

DAUBENMIRE, R. 1959. A canopy-coverage method of vegetational analysis. Northwest Sci. 33:43-64.

Delisle, J. M., AND J. A. SAVIDGE. 1996. Reproductive success of Grasshopper Sparrows in relation to edge. Prairie Nat. 28:107-113.

DIJAK, W. D. 1996. Landscape characteristics affecting the distribution of mammalian predators. M.Sc. thesis, Univ. Missouri, Columbia, MO.

Donovan, T. M., F. R. ThOMPSON, J. FAABORG, AND J. R. PROBST. 1995. Reproductive success of migratory birds in habitat sources and sinks. Conserv. Biol. 9:1380-1395.

Donovan, T. M., P. W. Jones, E. M. Annand, and F. R. ThOMPSON. 1997. Variation in local-scale edge effects: mechanisms and landscape context. Ecology 78:2064-2075.

FAaborG, J., M. Brittingham, T. M Donovan, AND J. BLAKE. 1993. Habitat fragmentation in the Temperate Zone: a perspective for managers, p. 331338. In D. M. Finch and P. W. Stangel [EDS.], Status and management of Neotropical migratory birds. U.S. Dept. Agriculture, Forest Service, GTR RM-229, Fort Collins, CO.

FRETWELL, S. 1984. Distribution and abundance of the Dickcissel. Current Ornithol. 4:211-242.

Gates, J. E., AND L. W. Gysel. 1978. Avian nest dispersion and fledging success in field-forest ecotones. Ecology 59:871-883. 
Greenwood, R. J., A. B. Sargeant, D. H. Johnson, L. M. Cowardin, AND T. L. ShafFer. 1995. Factors associated with duck nesting success in the prairie pothole region of Canada. Wildl. Monogr. 128.

HeRKERT, J. K. 1994. Breeding bird communities of midwestern prairie fragments: the effects of prescribed burning and habitat-area. Nat. Areas J. 14: 128-135.

Herkert, J. K., R. S. Szafone, V. M. KLeEn, and J. E. Schwegman. 1993. Habitat establishment, enhancement, and management for forest and grassland birds in Illinois. Division of Natural Heritage, Illinois Dept. Conserv., Springfield, IL.

HESKE, E. J. 1995. Mammal abundances on forest-farm edges versus forest interiors in southern Illinois: is there an edge effect? J. Mammal. 76:562-568.

Huhta, E., T. MapPES, AND J. JokimaKi. 1996. Predation on artificial ground nests in relation to forest fragmentation, agricultural land and habitat structure. Ecography 19:85-91.

JAMES, F. C. 1971. Ordinations of habitat relationships among breeding birds. Wilson Bull. 88:215-236.

JoHnSON, D. H. 1979. Estimating nesting success: the Mayfield method and an alternative. Auk 96:651661.

Johnson, D. H., A. B. Sargeant, and R. J. GreEnWOOD. 1989. Importance of individual species of predators on nesting success of ducks in the Canadian Prairie Pothole Region. Can. J. Zool. 67: 291-297.

Johnson, R. G., AND S. A. Temple. 1990. Nest predation and brood parasitism of tallgrass prairie birds. J. Wildl. Manage. 54:106-111.

KNOPF, F. L. 1994. Avian assemblages on altered grasslands. Stud. Avian Biol. 15:247-257.

Laurence, W. F., and E. Yensen. 1991. Predicting the impact of edge effects in fragmented habitats. Biol. Conserv. 55:77-92.

Lima, S. L., AND T. J. Valone. 1991. Predators and avian community organization: an experiment in a semi-desert grassland. Oecologia 86:105-112.

Lima, S. L., AND P. A. ZollNER. 1996. Towards a behavioral ecology of ecological landscapes. Trends Ecol. Evol. 11:131-134.

Major, R. E., and C. E. Kendal. 1996. The contribution of artificial nest experiments to understanding avian reproductive success: a review of methods and conclusions. Ibis 138:298-307.

MAYFIELD, H. F. 1975. Suggestions for calculating nesting success. Wilson Bull. 87:456-466.

Paton, P. W. 1994. The effect of edge on avian nest success: how strong is the evidence? Conserv. Biol. 8:17-26.

Peterjohn, B. G., and J. R. Sauer. 1993. Breeding bird survey annual summary, 1990-1991. Bird Populations 1:52-67.

PORNELUZi, P. 1996. Effects of forest fragmentation on Ovenbird biology. Ph.D. diss., Univ. Missouri, Columbia, MO.

PruITT, L. 1996. Henslow's Sparrow status assessment. U.S. Fish Wildl. Serv., Fort Snelling, MN.

Robinson, S. K., F. R. Thompson, T. M. Donovan, D. R. Whitehead, AND J. FAABORG. 1995. Regional forest fragmentation and the nesting success of migratory birds. Science 267:1987-1990.

Sargeant, G. A., D. H. Johnson, and W. E. Berg. 1998. Interpreting carnivore scent-station surveys. J. Wildl. Manage. 62:1234-1244.

SAS INSTITUTE. 1995. SAS/STAT user's guide, Release 6.03 ed. SAS Institute, Inc., Cary, NC.

SAS INSTITUTE. 1997. SAS/STAT software: changes and enhancements through release 6.12. SAS Institute, Inc., Cary, NC.

SMall, M. F., AND M. L. HunTER. 1988. Forest fragmentation and avian nest predation in forested landscapes. Oecologia 76:62-64.

Suarez, A. V., K. S. Pfennig, and S. K Robinson. 1997. Nesting success of a disturbance dependent songbird on different kinds of edges. Conserv. Biol. 11:928-935.

SWANSON, D. A. 1996. Nesting ecology and nesting habitat requirements of Ohio's grassland-nesting birds: a literature review. Ohio Fish Wildl. Serv. Report 13, Columbus, Ohio.

TEMPLE, S. A. 1986. Predicting impacts of habitat fragmentation on forest birds: a comparison of two models, p. 301-304. In J. Verner, M. L. Morrison, and C. J. Ralph [EDS.], Modeling habitat relationships of terrestrial vertebrates. Univ. Wisconsin Press, Madison, WI.

Thompson, F. R., W. DijaK, And D. E. Burhans. 1999. Video identification of predators at songbird nests in old fields. Auk 116:259-264.

WarnER, R. E. 1994. Agricultural land use and grassland habitat in Illinois: future shock for midwestern birds? Conserv. Biol. 8:147-156.

Whelan, C. J., M. L. Dilger, D. Robson, N. Hallyn, AND S. DILGER. 1994. Effects of olfactory cues on artificial nest experiments. Auk 111:945-952.

WINTER, M. 1998. Effect of habitat fragmentation on grassland-nesting birds in southwestern Missouri prairie fragments. Ph.D. diss., Univ. Missouri, Columbia, MO.

WINTER, M. 1999. Nesting biology of Dickcissels and Henslow's Sparrows in southwestern Missouri prairie fragments. Wilson Bull. 11:515-526.

Winter, M., AND J. FAABORG. 1999. Patterns of area sensitivity in grassland-nesting birds. Conserv. Biol. 13:1424-1436.

Zimmerman, J. L. 1984. Nest predation and its relationship to habitat and nest density in Dickcissels. Condor 86:68-72. 